\title{
Św. Ireneusz z Lyonu i jego argumentacja przeciw gnostykom
}

\author{
Ks. Andrzej Kuźma \\ Wydział Teologiczny, Chrześcijańska Akademia Teologiczna w Warszawie \\ Polska \\ akuzma65@wp.pl
}

Rev. Andrzej Kuźma, St. Irenaeus and his arguments against the Gnostics, Elpis 17 2015: 145-151.

\begin{abstract}
This article presents St. Irenaeus and characterizes his literary work. The origins of Gnosticism are discussed and the main leaders of this movement at the turn of the third century are presented. Next, the places in which St. Irenaeus reveals orthodox teaching when combating Gnostic views, which threatened the existence of the Church, are outlined. These points concern anthropology, the theory of recapitulation, and the Tradition and apostolicity of the Church. While exposing the Gnostic's false teaching, St. Irenaeus bears witness to the true teaching of the Church.
\end{abstract}

\begin{abstract}
Abstrakt: Artykuł przedstawia postać św. Ireneusza i charakteryzuje jego dzieła literackie. Omówiona została geneza gnostycyzmu i ukazani zostali główni przedstawiciele tego nurtu okresu przełomu II/III w. Następnie zostały przedstawione punkty, w których św. Ireneusz zwalczając poglądy gnostyków jako zagrażające bytowi Kościoła ukazuje prawowierną naukę. Te punkty dotyczą: antropologii, teorii rekapitulacji, tradycji i apostolskości Kościoła. Św. Ireneusz demaskując fałszywe nauczanie gnostyków dał wykład prawdziwej nauki kościelnej.
\end{abstract}

Keywords: St. Irenaeus of Lyons, Gnosticism, fight with Gnosticism, the theory of recapitulation, the apostolicity of the Church, Apostolic Tradition

Słowa kluczowe: Św. Ireneusz z Lyonu, gnostycyzm, walka z gnostycyzmem, teoria rekapitulacji, apostolskość Kościoła, Tradycja apostolska

Bez wątpienia można stwierdzić, że św. Ireneusz jest najważniejszym teologiem II wieku. Jego pisma nie posiadają charakteru typowo apologetycznego jak np. teksty św. Justyna Filozofa czy Tertuliana i z tego względu raczej nie zalicza się do grona apologetów w ścisłym znaczeniu tego słowa. Niemniej jednak charakter jego twórczości jest nacechowany obronną postawą wobec gnostyków i skutecznym odpieraniem ich zarzutów. Przy sposobności zwalczania gnostyków, Ireneusz rozwija szereg nurtów chrześcijańskiego nauczania, które pozostaną aktualne w późniejszym okresie życia Kościoła.

Nie znamy dokładnej daty urodzin św. Ireneusza. Wiemy natomiast, że był uczniem i bliskim współpracownikiem św. Polikarpa ze Smyrny a tym samym był związany z tradycją pochodzącą od św. Jana Ewangelisty. W liście skierowanym do swego przyjaciela Floryna, Ireneusz wspomina jak obaj w dzieciństwie słuchali Polikarpa, biskupa Smyrny który opowiadał o swych rozmowach z Janem i innymi, którzy widzieli Pana: „(...) mogę wskazać nawet miejsce, gdzie błogosławiony Polikarp siadał i przemawiał, jak wchodził i wychodził, jaki był tryb jego życia (...) jak przemawiał do ludu, jak opowiadał o swych stosunkach z Janem i z innymi, którzy widzieli Pana (...). Tego ja wówczas chciwie słuchałem, dzięki zmiłowaniu, jakie mi Bóg okazał i przechowałem to w pamięci, nie na papierze, ale w swym sercu" 1 . Przyjmując datę męczeńskiej śmierci św. Polikarpa w 156 r.

Euzebiusz z Cezarei, Historia Kościelna V,20,6. uczeni uważają, że datę narodzin św. Ireneusza należałoby określić na lata 130-140². Pochodził z Azji Mniejszej i urodził się w prawdopodobnie w Smyrnie (dzisiejszym Izmirze w Turcji), gdzie też spędził swoje dzieciństwo. Nie jest też wykluczonym, że urodził się w innym mieście. Efez i Smyrna w środowisku kościelnym cieszyły się dużym autorytetem, z tego względu, że przez długi okres czasu przebywał tam apostoł św. Jana Ewangelista. W ten sposób Kościół W Azji Mniejszej był związany z tradycją Janową. Dlatego też relacje ze „starszymi” czyli prezbitrami, od których św. Ireneusz zdobywał wiedzę i którzy nawiązywali do nauki św. Jana pozwalało patrzeć jemu na ten Kościół jako będący głęboko zakorzeniony w tradycji apostolskiej. Nie znamy dokładnie powodu dla jakiego przeniósł się z Azji Mniejszej na Zachód. Możemy przypuszczać, że podobnie jak wielu emigrantów z Azji Mniejszej, św. Ireneusz z pewnych powodów przeniósł się do zachodniej części cesarstwa. Nie jest wykluczonym, że przybył wraz ze św. Polikarpem do Rzymu i towarzyszył mu w czasie rozmów z biskupem Rzymu Anicetem (155-166) odnośnie rozbieżności świętowania Wielkanocy według tradycji Mało Azjatyckiej i zachodniej ${ }^{3}$. W 177 r. był już prezbitrem gminy chrześcijańskiej w Lyonie (łac. Lugdunum) i jak świadczy Euzebiusz został wysłany do Rzymu z polecającym listem od biskupa tegoż

\footnotetext{
Zob. W. Myszor, Wstęp do: Ireneusz z Lyonu, Wykład nauki apostolskiej, Kraków 1997, s. 5.
}

3 DTC, t. 7/II, Paris 1924, col. 2395. 
Lyonu w sprawie dotyczącej montanistów: „Zleciliśmy Ireneuszowi, bratu naszemu i towarzyszowi by ci wręczył listy i prosimy cię, byś go przyjął łaskawie. Gdybyśmy sądzili, że znamię czystej sprawiedliwości polega na stanowisku, tedy byśmy tobie przedstawili przede wszystkim jako prezbitra Kościoła, czym jest też w rzeczy samej”4. Prawdopodobnie w roku 178 po męczeńskiej śmierci biskupa Lyonu, Potinosa został jego następcą. Nie zachowały się żadne informacje dotyczące jego edukacji, z pism możemy jednak wnioskować, że odbył poważne studia literatury i retoryki, jak również w znaczącym stopniu był obeznany z filozofią. Jego ojczysty język grecki w tym czasie był używany jeszcze na zachodzie jako język liturgiczny i rozumiano go we wszystkich ważniejszych zachodnich miastach ${ }^{5}$.

Nie posiadamy jasnych informacji z okresu kiedy pełnił funkcję biskupa Lyonu, niemniej jednak często postrzegany jest jako rzeczywisty zwierzchnik młodego Kościoła w Galii'. Z jego nielicznych dziejów biograficznych, posiadamy informacje dotyczące interwencji w Rzymie w sprawie daty świętowania Wielkanocy. Biskup rzymski Wiktor (189-198), ostro sprzeciwił się praktyce obchodzenia tego święta w dniu 14 Nissana, tj. praktyki tzw. Kwartodecyman, którzy obchodzili ten dzień w tym samym czasie co Żydzi. Praktyka ta była szeroko stosowana w Azji Mniejszej, tzn. w Kościołach związanych z tradycją Janową. Problem ten nie był nowym, już św. Polikarp próbował rozwiązać ten problem wraz z papieżem Anicetem ok. 154r. Tym razem odżył na nowo i próby jego rozwiązania w czasie pontyfikatu papieża Wiktora ok. 190 r. powróciły na nowo. Tradycja Janowa nawiązywała do pojmowania chrześcijańskiej Paschy jako do zdarzenia, które miało miejsce w Wieczerniku, tj. do Wieczerzy, którą spożył Pan wraz z uczniami ustanawiając jednocześnie sakrament Eucharystii. Zdarzenie to miało miejsce w tym samym czasie co Pascha żydowska i tak też wspominano to wydarzenie w Kościołach Małej Azji. Prawdopodobnie w wyniku emigracji i osiedlania się $\mathrm{w}$ stolicy ludności pochodzącej z różnych zakątków cesarstwa, w tym też chrześcijan z Azji Mniejszej, którzy obchodzili to święto według własnej tradycji, w Kościele rzymskim zapanował pewien nieporządek. Tradycja wielu Kościołów na czele z Kościołem rzymskim nakazywała świętowanie Zmartwychwstania Chrystusa w niedzielę po Pasze Żydowskiej. I tak w Kościele rzymskim część chrześcijan obchodziła chrześcijańską Paschę, przy tym jak znacząca część Kościoła trwała jeszcze w okresie postu. Św. Ireneusz napisał szereg listów do biskupów w tym do papieża Wiktora, nawołując do zachowania pokoju z tymi, którzy obchodzą to święto w innym terminie. Zasadniczym argumentem św. Ireneusza przemawiającym za tym, że chrześcijanie z Azji Mniejszej mają prawo świętować Wielkanoc według własnej tradycji jest fakt, że Kościół ten został założony przez św. Jana i nie może on w swoim nauczaniu być sprzeczny ze słowami Pana. Taka tradycję należy uznać za

\footnotetext{
Euzebiusz z Cezarei, dz. cyt. V,4,2.

Zob. И. Мейендорф, Введение в святоотеческое богословие, New York 1985 s. 31.

6 DTC, t.7/II, col. 2396.
}

ważną i dobrą̧ ${ }^{7}$ Rozbieżności co do daty świętowania Wielkanocy nie stały się jednak powodem podziału w Kościele. W IV w. na I Soborze Powszechnym przyjęto zasadę, która funkcjonowała w większości Kościołów, w tym i w Kościele zachodnim, że Pascha chrześcijańska będzie obchodzona w pierwsza Niedzielę po Passze żydowskiej.

Dalsze koleje losu Św. Ireneusza są nam nieznane. Wiemy, że zginął śmiercią męczeńską wraz z innymi mieszkańcami Lyonu. Św. Hieronim (345-419), a potem św. Grzegorz z Tours (538-594), podają informację, że miało to miejsce ok. 200 r. Przekaz ten jest dość późnym, niemniej jednak ten rok przyjmowany jest jako data śmierci św. Ireneusza.

\section{Pisma}

Św. Ireneusz jest postrzegany przede wszystkim, jako Ojciec Kościoła i pisarz chrześcijański, który swój intelekt skierował przeciwko pismom gnostyckim i zwalczaniu tych poglądów, które w II w. rozprzestrzeniły się w Kościele na niebywała skalę. Wiele jego pism zachowało się jedynie we fragmentach. Dotarły jednak w całości do naszych czasów jego dwa bardzo ważne pisma: 1) Pięć Ksiąg Przeciwko Herezjom i 2) Wykład nauki Apostolskiej.

1. Pięć Ksiag Przeciwko Herezjom, zachowało się w przekładzie łacińskim. Kompletny tytuł brzmi: Zdemaskowanie i odparcie fatszywej wiedzy (łac. Adversus haereses). Powodem napisania tego dzieła była prośba przyjaciela Ireneusza, który chciał zapoznać się z systemem gnostyckim:

- w 1-szej Księdze przedstawia autor systemy gnostyckie, przeciwstawiając je nauce Kościoła. Przedstawienie tej fałszywej nauki nazywa „zdemaskowaniem” po to by w następnych księgach przystąpić do „zbicia” fałszywych argumentów:

- w 2-giej Księdze przedstawia doktrynę walentynian i marcjonitów, odrzucając ich poglądy na podstawie rozumu

- w 3-ciej zwalcza poglądy swych przeciwników na podstawie nauki Kościoła, przekazanej przez Apostołów

- w 4-tej na podstawie słów Pana

- 5-ta księga mówi o rzeczach ostatecznych, przede wszystkim o zmartwychwstaniu, które było negowane przez gnostyków ${ }^{8}$.

2. Wykład Nauki Apostolskiej. Pismo to było znane z tytułu m. in. dla Euzebiusza z Cezarei ${ }^{9}$, ale dopiero w 1904 r. zostało odnalezione $\mathrm{w}$ ormiańskim przekładzie i w 1907 r. opublikowane i stało się obiektem studiów ${ }^{10}$. Wbrew pozorom tekst nie jest wykładem katechetycznym, lecz podobnie jak poprzednie dzieło posiada

\footnotetext{
Zob. Euzebiusz z Cezarei, dz. cyt. V,24,16-17.

8 Dzieło to powstało prawdopodobnie w latach 180-185, na prośbę przyjaciela św. Ireneusza. Zob. W. Myszor, Gnostycyzm i teologia Ireneusza $z$ Lyonu, Studia Antiquitatis Christianae, Series Nova 11, red. L. LachMbartlik, Katowice 2010, s. 47.

9 Zob. Historia Kościelna V,26.

10 Zob. J. Quasten, Initiation aux Pères de l'Église, t. 1, Paris 1955, s. 335.
} 
charakter apologetyczny. Część I (Rozdziały 1-42) przedstawia wiarę chrześcijańską. Bóg, Trójca Święta, Stworzenie, Upadek, Odkupienie. Część II (Rozdziały 42-100) podaje dowody ze Starego Testamentu odnośnie proroctw o Jezusie, synu Dawida.

\section{Gnostycyzm}

Gnostycyzmem (gr. $\gamma v \omega \dot{\sigma} \sigma \varsigma$, gnozis- wiedza, poznanie) określa się dualistyczne nurty religijno-filozoficzne, które zaistniały w II i III w. po Chrystusie, obejmujące szereg systemów i ruchów ${ }^{11}$. Początkowa faza ruchów związanych z gnozą jest próbą połączenia greckiej myśli filozoficznej z wschodnimi kultami mistycznymi i datowana jest na okres styku dwóch epok tj. I w. p.n.e. i I w. n.e. Natomiast pierwsze systemy gnostyckie o zabarwieniu judeochrześcijańskim pojawiły się prawdopodobnie ok. roku 70. Już apostoł Paweł przestrzegał Tymoteusza w swoim Liście: „Tymoteuszu, strzeż depozytu [wiary] unikając światowej czczej gadaniny i przeciwstawnych twierdzeń rzekomej wiedzy ( $\gamma v \omega \dot{\omega} \iota \varsigma$, gnosis), jaką obiecując, niektórzy odpadli od wiary" (1Tm 6,20). Jednak prawdziwy rozkwit tych ruchów przypada na II wiek. Nurty gnostyckie, które stanowiły zagrożenie dla kształtującej się nauki chrześcijańskiej w znaczącej mierze opierały swoją teorie o nauczanie chrześcijańskie i właściwie gnostycy uważali siebie za chrześcijan. Dlatego też, głosząc odmienne nauczanie niż to, które głosił Kościół, w oczach św. Ireneusza systemy gnostyckie i ich głosiciele stanowiły ogromne zagrożenie.

Zasadniczą cechą światopoglądu gnostyckiego było pesymistyczne podejście do świata. Gnostycy odrzucali świat, który wyrażony został za pomoca filozoficznego terminu „kosmos” tj. świat widzialny i nie widzialny, który obejmował sobą bogów i ludzi w ujęciu filozofii greckiej. Gnostycy odrzucali też świat jako stworzenie Boże w ujęciu biblijnym. Świat pojmowali jako pełen zła i nieszczęść. Ten świat należało odrzucić i z niego uwolnić sięę ${ }^{12}$ Nurtów gnostyckich powstało wiele, ale wszystkie one charakteryzowały się twierdzeniem o dwóch bóstwach:

1. wyższego, transcendentnego i niepojętego, jak też

2. niższego, demiurga, który rządzi naszym światem ziemskim.

Przy czym niższe bóstwo utożsamiali ze Staro Testamentowym Bogiem Stworzycielem świata. Źródło wszelkiego zła gnostycy upatrywali w materii. Będąc złą w swojej istocie, materia nie może pochodzić do Boga (tego wyższego), ani być od niego zależna. Jeśli w świecie istnieje złe bóstwo, to przyczyną tego jest to, iż złączyło się ono z materią. Świat złączony z materią nie może pochodzić od Boga. Ten gnostycki dualizm w konsekwencji oddzielał stwórcę świata od rzeczywistego i prawdziwego Boga w rozumieniu biblijnym. W konsekwencji gnostycy w świecie obserwowali ciągłą walkę dwóch czynników: dobra i zła, światłości

\footnotetext{
11 Zob. dokładną definicję „gnostycyzmu” i „gnozy” W. Myszor, Gnostycyzm i teologia Ireneusza z Lyonu ..., s. 44.

12 Tamże 44-45.
}

i ciemności ${ }^{13}$. Przenosząc swoje teorie na grunt antropologiczny, gnostycy uważali, że zbawienie polega na oddzieleniu duszy od ciała. Dusza, która nie posiada pierwiastka materialnego jest swego rodzaju promieniem światła i cząstką najwyższego ducha znajdującego się w człowieku pozostaje uwięziona w ciele. Ciało jako materia pochodzi od złego bóstwa i stanowi swego rodzaju więzienie dla duszy.

Tematyka pism gnostyckich, pomimo swej różnorodności odnosi się do kilku tematów, które są im wspólne, tj.: 1) o Bogu i jego przymiotach, 2) o wielkim upadku związanym $\mathrm{z}$ powstaniem materii tj. świata i stworzenia człowieka i 3) wysłania zbawcy, który poprzez swoją przekazaną wiedzę (gnozę) daje zbawienie ${ }^{14}$. Gnostycy nie podważali zasadniczej roli jaką odegrał Jezus Chrystus w dziele zbawienia. Chrystus był wysłannikiem najwyższego, który przekazał ludziom wiedzę. Najwyższy Duch zesłał ludziom swego najwyższego Eona, który łącząc się z Jezusem dał ludziom środki i wiedzę, które umożliwiają oswobodzenie się od materii, a tym samym od zła. Wiedzę tę posiedli jednak nieliczni. Gnostycy odrzucali pojęcie wcielenia Syna Bożego, jak też realność jego zmartwychwstania.

Takie skomplikowane nauczanie, podkreślające jednocześnie rolę Chrystusa w zbawieniu, powodowało, że wielu szukających prawdy życia w ten czy inny sposób wstępowało do rodzących się sekt. Generalnie Gnostycy uważali siebie za chrześcijan, propagowali rygorystyczny ascetyzm i jednocześnie krytykowali Kościół za zbyt liberalne i nie dość rygorystyczne podejście do dyscypliny ascetycznej. Nazywali siebie „wybranymi”, „dziećmi światłości”, „duchownymi”, „niezmiennego rodu”, „doskonałymi”, „prawdziwymi”"15. Dlatego też w tym okresie Kościół stanął wobec głębokiego kryzysu doktrynalnego. Ruchy gnostyckie rodziły się w mesjanistycznych środowiskach miast, które były skupiskiem wielu napływowych kultur, zwłaszcza Azji i Antiochii. Znakomity grunt dla rozwoju stanowiła Aleksandria i Rzym.

Pierwszym znaczącym gnostykiem w Aleksandrii był Karpokrates (ok. 120r.). Informacje o nim zachowały się jedynie w pismach św. Ireneusza z Lyonu i Klemensa Aleksandryjskiego. Adepci jego twierdzili, że świat został stworzony przez aniołów, istoty o wiele niższe jak Niezrodzony Ojciec. Jezus był synem Józefa i niczym nie odróżniał się od innych ludzi. Natomiast dusza Jezusa postępowała zgodnie z wolą Boga i była sprawiedliwsza od dusz innych ludzi. Poprzez zstąpienie mocy bożej na duszę Jezusa, zdołał on pokonać duchy i aniołów, które były wrogami ludzkości. Po okresie przebywania na ziemi i nauczaniu ludzi, po swojej śmierci Jezus wrócił do nieba. Cuda, których dokonał na ziemi wcale nie dowodziły boskiej natury, lecz były tylko wynikiem uzdolnień pochodzących od Boga. Podobnych rzeczy dokonywali też inni prorocy, dlatego też wielu karpokracjan uważało, że są równi Jezusowi ${ }^{16}$.

Innym znaczącym przywódcą ruchu był Bazylides

\footnotetext{
13 W. Tatarkiewicz, Historia Filozofii, t. I, Warszawa 1988, s. 176-177.

14 W. Myszor, Gnostycyzm i teologia Ireneusza z Lyonu ..., s. 60.

15 Tamże, s. 63

16 F. Drączkowski, Patrologia, Peplin-Lublin 1999, s. 93-94.
} 
i jego syn (być może „syn” w znaczeniu ucznia) Izydor. Bazylides pochodził z Syrii, ale jego działalność została rozwinięta w Aleksandrii. Przypisywane jest mu autorstwo własnej ewangelii i szeregu pism egzegetycznych, które do naszych czasów zachowały się jedynie we fragmentach. Ważnym również ośrodkiem gnostycyzmu stał się Rzym, gdzie działalność rozwinął egzegeta Marcjon z Synopy. Gnostycy właściwie nie stanowili zwartych wspólnot i niewiele uwagi przydawali formom organizacyjnym. Dlatego, pod koniec III wieku zostali wchłonięci przez Manicheizm, który z jednej strony jawi się jako kontynuacja Gnostycyzmu, z drugiej zaś, posiadał strukturę organizacyjną na wzór Kościoła. Marcjon w odróżnieniu od większości Gnostyków II wieku, zdołał stworzyć dość trwałe struktury organizacyjne z biskupami i prezbitrami. Współczesne badania wykazują, że Marcjon w swoich poglądach nawiązywał bardziej do chrześcijaństwa niż do gnostycyzmu ${ }^{17}$. Niemniej jednak w swoich poglądach odrzucał Stary Testament, by w ten sposób oczyścić Ewangelię od „naleciałości żydowskich". Ponadto w swoim pesymistycznym podejściu do stworzonego świata charakteryzował się rygoryzmem moralnym, co z kolei prowadziło do krytyki Kościoła. Marcjonici stanowili zwartą sektę w II i III w. na terenie całego cesarstwa, ale tak jak pozostali gnostycy zostali wchłonięci przez manicheizmem. Do gnostyków zaliczany też jest Walentyn, który działał zarówno w Rzymie jak i w Aleksandrii. Jego poglądy również jak Marcjona zawierały wiele nauki chrześcijańskiej przeplatanej ideami gnostyckimi. Walentyn miał wielu uczniów, do jego zwolenników należał Bardesanes, który z tego ruchu wydzielił odrębną sektę zwaną bardesanitami. Uczniowie Walentyna bardziej niż ich nauczyciel skłonili się w kierunku gnostycyzmu.

Gnostyckie grupy z II w. posługiwały się religijnymi tekstami zarówno żydowskimi jak i chrześcijańskimi dokonując ich interpretacji alegorycznej. Do tej interpretacji używano często tekstów apokryficznych ewangelii, listów, apokalips. Interpretując już istniejące teksty apokryficzne, gnostycy tworzyli też własne, takie jak: Księga Tomasza, Ewangelia Filipa, Ewangelia Marii Magdaleny, Ewangelia Judasza, Dzieje Piotra i Dwunastu Apostołów i in.

Biskup Lyonu zaniepokojony nadejściem takich nauk, które rozprzestrzeniają się wszędzie, uważa, że ich twórcy odwracają się od Boga Jedynego, który jest Stwórcą świata. Świat, który On stworzył jest dobry, gnostycy twierdzą natomiast, że świat jest zły. Św. Ireneusz uważa, że bluźnią oni przeciwko Chrystusowi i zaprzeczają Wcieleniu Słowa. Zamierza więc ukazać owe nauki po to, by potem je zwalczać i ukazać prawdziwą naukę Chrystusową.

\section{Nauka św. Ireneusza}

Nauka i poglądy św. Ireneusza w znaczącej mierze wyrosły na gruncie polemiki z gnostycyzmem i poglądami heteroortodoksyjnymi. Swoim zasięgiem jego poglądy

17 Zob. W. Myszor, Gnostycyzm i teologia Ireneusza z Lyonu ..., s. 55. obejmują szeroki zakres nauki chrześcijańskiej i odnoszą się niemalże do wszystkich dziedzin teologii.

\section{Antropologia}

Jego nauka o człowieku wyrosła na bazie odrzucania i krytyki poglądów gnostyków, którzy negowali znaczenie ciała człowieka. Ireneusz pojmował człowieka jako całość, gdzie zarówno duchowa część jak i materialna stanowią jego integralną całość. Zasadniczo widział w człowieku trzy aspekty - ducha, duszę i ciało. Chociaż w swoim „Wykładzie nauki Apostolskiej” wyraźnie mówi o dwóch częściach składowych człowieka: „Człowiek, ponieważ jest istotą złożoną $\mathrm{z}$ duszy i ciała, wypada i trzeba, aby określał siebie przez te dwie części” (Wykład 2). Jednak najczęściej św. Ireneusz skłonny jest mówić o człowieku złożonym z trzech elementów: „Doskonały człowiek, tak jak wykazaliśmy składa się z trzech części: ciała, duszy i ducha. Spośród których, jeden tj. duch zbawia i tworzy, drugi (element) zaś tj. ciało jest tworzone i zbawiane; środkowa między nimi (część) tj. dusza, kiedy postępuje za duchem jest podwyższana przez niego, a czasem kiedy podporządkowuje się ciału popada w ziemskie pożądliwości” (AH. V.9.1). Według powyższego schematu człowiek uzależniony jest od działania w nim ducha, który skłania duszę do czynienia rzeczy Bożych i ciała, które skłania człowieka do czynienia rzeczy złych. W nauce Ireneusza występuje pewna nieścisłość, kiedy mówi on o tym trzecim elemencie natury ludzkiej, mianowicie o duchu. Brak jest wyraźnej granicy, kiedy mówi o duchu Bożym i duchu człowieka. Według niego to właśnie duch jest tym czynnikiem, który skłania człowieka do czynienia dobra lub oddawania się złu. Jednak u biskupa Lyonu takie rozgraniczenie posiada swój sens. Prawdopodobnie zwalczając poglądy gnostyków, którzy twierdzili, że dusza bez względu na jej postawę moralną jest tą lepszą częścią człowieka, św. Ireneusz wprowadza pojęcie ducha Bożego, który skłania duszę do czynienie dobra tj. ciągłego wzrastania i doskonalenia się, jak też ducha ludzkiego, który prowadzi w inną stronę tj. przydawaniu większej wartości ciału ${ }^{18}$.

W swoich pismach, zarówno w Przeciwko Herezjom jak też Wykładzie nauki Apostolskiej porusza zagadnienie stworzenia człowieka przez Boga. Uważa, że Bóg tworząc świat, stworzył go doskonałym i zakończonym w swoim procesie tworzenia. Natomiast człowiek, któremu ten świat był dany we władanie nie posiadał takiej doskonałości. Naturę pierwszego człowieka porównuje do natury dziecka, którego głównym zadaniem było wzrastanie i doskonalenie się. Pierwszy człowiek miał za zadanie rozwijać się aby na końcu osiągnąć pełną dojrzałość, w podobny sposób cała ludzkość jest wezwana do przejścia ze stanu dziecięctwa do dojrzałości: „Dlatego też Słowo Boże, które było doskonałym stało się dzieckiem razem z człowiekiem, nie dla niego samego, ale $\mathrm{z}$ powodu stanu dziecięctwa w którym przebywał człowiek, aby osiągnąć to co człowiek

18 Zob. J. Quasten, dz. cyt. s. 356-357. 
będąc w tym stanie mógł osiągnąc" (AH. IV,38,2). Człowiek z jednej strony otrzymał od Boga w akcie tworzenia obraz i podobieństwo do Stwórcy i jednocześnie do pełni podobieństwa miał jeszcze wzrastać. Swoją doskonałość człowiek miał dopiero osiągnąć. Na postawione przez siebie pytanie, czy Bóg mógł stworzyć człowieka w pełni doskonałym, św. Ireneusz odpowiada, że Stwórca mógł tak zrobić. Jednak dla dobra całego bytu wybrał człowiekowi drogę wzrastania i upodabniania się do Twórcy poprzez wysiłek, własną twórczość i współpracę z Bogiem (AH. IV,38,1). Z takiej niedoskonałości natury człowieka, biskup Lyonu wywodzi też przyczynę jego upadku i oddalenia się od Stwórcy. Mianowicie posiadając naturę dziecka, Adam stanowił łatwą zdobycz dla szatana: „Człowiek był jeszcze dzieckiem i miał niedojrzałą wolę, dlatego łatwo został zwiedzony przez uwodziciela" (Wykład 12). Podobnie Ewa, która była wzięta z żebra Adama (Rdz. 2,23), również posiadała naturę dziecka i podobnie jak pierwszy człowiek jej głównym zadaniem było wzrastanie. Koncepcja stanu dziecięctwa Adama i jego upadku jako niedoskonałego stworzenia, jest dość oryginalną nauką, którą wysuwa św. Ireneusz. Odpowiada ona na zarzuty gnostyków, którzy, twierdzili o niedoskonałości materii, która została stworzona przez „złego boga”. Bóg Twórca jest dobrym przekonuje św. Ireneusz, to co zaś stworzył również przeznaczone jest do doskonałości.

\section{Nauka o zbawieniu - rekapitulacja}

Bardzo ważnym punktem w nauczaniu św. Ireneusza o Synu Bożym jest rola jaką Chrystus odegrał w odnowieniu całego stworzenia. Odbudowę tej jedności św. Ireneusz określa używając wyrażenia apostoła Pawła - rekapitulacją

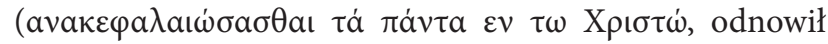
(zrekapitulował) wszystko w Chrystusie, Ef. 1.10). Grecki

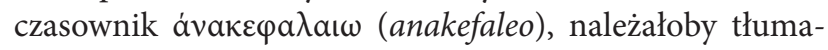
czyć opisowo jako „ustanowienie głowy na swoim miejscu”, lub „przywrócenie głowy”'19. Taki też sens posiada to wyrażenie w j. łacińskim - recapitulare. Rekapitulacja dla św. Ireneusza posiada wymiar soteriologiczny, jest odbudową planu zbawienia człowieka, który był założony na początku i został przerwany przez upadek Adama. Podkreślenie zbawiennej roli Chrystusa jako Zbawiciela również jest wycelowane przeciwko gnostykom, którzy postrzegali Jezusa raczej jako proroka lub nauczyciela, który przyniósł objawioną naukę od samego Boga, a nie tego, który poprzez swoje wcielenie odnowił całą ludzkość.

Bóg tworząc człowieka, stworzył go aby ten wzrastał i doskonalił się w Bogu. Jednak Adam nie podołał temu zadaniu. Proces doskonalenia się człowieka został przerwany. Jednak Stwórca nie pozostawił swojego dzieła, w które włożył swój obraz (Rdz. 1,26), nie pozostawia

\footnotetext{
19 Zob. szczegółową analizę tego terminu: T. Dekert, Teoria rekapitulacji Ireneusza z Lyonu w świetle starożytnych koncepcji na temat Adama, Kraków 2007, s. 17-29.
}

człowieka własnej rozpaczy i beznadziejności lecz daje obietnicę pojednania. Poprzez upadek pierwszego człowieka została naruszona wspólnota człowieka z Bogiem, została zatracona pierwsza jedność. Chrystus przychodzi po to aby odbudować tą jedność i pojednać człowieka z Bogiem. Odbudowa tej jedności jest zjednoczeniem w Chrystusie jako Głowie. W Chrystusie dokonuje się zjednoczenie świata niebieskiego i ziemskiego nie pomijając również zjednoczenia człowieka z Bogiem. Bóg jak gdyby przywraca głowę swojemu stworzeniu. Stwórca odnawia swoje dzieło, aby je odtworzyć i przeorganizować we wcielonym Synu, który jest w ten sposób dla nas nowym Adamem. Apostoł Paweł w swoich listach niejednokrotnie nazywał Chrystusa drugim Adamem, przeciwstawiając jednocześnie pierwszemu: „Pierwszy człowiek jest z prochu ziemi - ziemski, drugi Człowiek z nieba. Jaki ów ziemski, tacy i ziemscy; jaki ten niebieski, tacy i niebiescy" (1 Kor 15,47). Wcielenie Syna Bożego było podyktowane jedną przyczyną: uratowaniem człowieka, a przez niego reszty stworzenia, dlatego też Nowy AdamChrystus powinien był przyjąć na siebie takie samo ciało jakie miał Adam upadły: „Jeśli Pan stał się człowiekiem według innego porządku i przyjął ciało z jakiejś innej substancji, to nie zrekapitulowałby w sobie człowieka i nie może być w ogóle nazwany ciałem. Ciało, bowiem jest rzeczywiście następstwem pierwotnego stworzenia uczynionego z ziemi. Jeśli, więc miałby mieć materię z jakiejś innej substancji, to od początku Ojciec musiałby działać na podstawie innej substancji dla zbudowania Jego bytu. Tymczasem zbawcze Słowo stało się człowiekiem, tym samym człowiekiem, który zginął" (AH. V,14,2). W planie Boskiej ekonomii, warunkiem odbudowania upadłego bytu było zstąpienie za ziemię samego Boga. Dlatego też św. Ireneusz kontynuuje: „Teraz zbawcze Słowo stało się tym, kim był upadły człowiek. Przez siebie Syn Boży doprowadził do relacji ze sobą człowieka osiągając jego zbawienie. To co upadło posiadało krew i ciało, dlatego, że Pan biorąc kawałek ziemi stworzył człowieka, dla którego dokonało się przyjście Pańskie. On sam będąc z ciała i krwi odnowił (zrekapitulował) w Sobie pierwotne stworzenie Ojca, odnajdując zaginionego" (AH. V,14,2). Poprzez to odnowienie człowieka pierwotnego, nie tylko osoba Adama, ale cały rodzaj ludzki został odnowiony i odbudowany ${ }^{20}$. Tak jak poprzez Adama cały rodzaj ludzki znalazł się w upadku, tak też poprzez Chrystusa następuje odnowienie wszystkich ludzi, tzn. tak jak skutkami grzechu pierwszych ludzi dotknięci zostali wszyscy ludzie to i zbawienie w Chrystusie również dotyczy wszystkich : „Gdy Chrystus przyjął ciało i stał się człowiekiem, zrekapitulował w sobie długi szereg ludzkości i dał nam w tym ujęciu zbawienie, tak że cośmy stracili w Adamie (być na obraz i podobieństwo Boże) tośmy odzyskali w Jezusie Chrystusie" (AH 3,18,1).

Niwecząc skutki nieposłuszeństwa pierwszego Adama, Bóg odbudował w Chrystusie to ciało człowieka, które niegdyś stworzył dla chwały. Św. Ireneusz w swojej nauce

\footnotetext{
20 Zob. Tamże s. 38.
} 
o rekapitulacji często powraca i podkreśla aspektu nieposłuszeństwa pierwszego człowieka i posłuszeństwa Chrystusa. Kuszenie chlebem na pustyni : „Jeśli jesteś Synem Bożym, powiedz, żeby te kamienie stały się Chlebem" (Mt. 4,3) są analogią do kuszenia „owocem” w Raju. W przypadku owocu w Raju, staje się on pokarmem nieposłuszeństwa, zatracenia i grzechu, natomiast jeśli chodzi o chleb na pustyni sytuacja nabiera innego wymiaru. Chrystus poprzez swoje posłuszeństwo woli Bożej odrzuca grzech i w ten sposób ukazuje każdemu człowiekowi jak należy postępować. Ludzkość w Adamie uczyła się grzechu, natomiast w odnowieniu Chrystusa uczy się walki z grzechem (Zob. AH. V,21,2).

Analogicznie do koncepcji Chrystusa nowego Adama, przez którego człowiek odzyskuje to co stracił w starym Adamie, św. Ireneusz akcentuje rolę Maryi jako nowej Ewy. Biskup Lyonu tak jak w przypadku relacji Adam - Chrystus, ukazuje szereg analogii pomiędzy Ewą i Maryją. Pierwsza z nich dotyczy nieposłuszeństwa pierwszej i posłuszeństwa drugiej. Ewa w Raju, kosztując owocu „poznania dobra i zła" zgrzeszyła nieposłuszeństwem wobec Stwórcy. Adam poddając się namowom Ewy sprowadził na ludzkość grzech i oddalenie się od Boga. W działaniu Maryi, pasterz Lyoński obserwuje naprawę tego co zniszczyła Ewa. W czasie Jej zwiastowania, kiedy słyszy zapowiedź o tym, że porodzi Syna, odnowione jest dawne posłuszeństwo: „Tak, więc węzeł nieposłuszeństwa znalazł rozwiązanie przez posłuszeństwo Maryi. Co Ewa dziewica splątała przez niewierność, Maryja dziewica rozwiązała przez wiarę" (AH. III,22,4). Postawa Maryi jest przykładem doskonałych relacji ze Stwórcą. Poprzez swoją postawę Maryja stała się przyczyną zbawienia całej ludzkości. Poprzez swoje posłuszeństwo stała się Bogorodzicą. Tak jak poprzez pierwszą Ewę ludzkość wpadła w grzech i ciemność, to dzięki drugiej Ewie światu ukazała się Jasność i to Ona okazała się tą, która „starła głowę węża” (AH. IV,40,3).

Św. Ireneusz pogłębiając naukę o odnowieniu człowieka i całego stworzenia w Chrystusie podkreśla znaczenie odkupienia jakie właśnie dokonało się przez Niego. Chrystus stał się człowiekiem po to by ludzkość została przebóstwiona. Nauka o przebóstwieniu została zapoczątkowana właśnie przez św. Ireneusza. Stała się ona charakterystyczna dla chrześcijańskiego wschodu i kontynuowana przez późniejsze pokolenia Ojców Kościoła (św. Atanazy Wielki, św. Grzegorz Teolog, św. Maksym Wyznawca i in.). $\theta \dot{\varepsilon} \omega \sigma \eta \varsigma$, theozis (gr.), - przebóstwienie człowieka było zasadniczą misją Zbawiciela: „Słowo Boże, Jezus Chrystus, nasz Pan z powodu niezmierzonej miłości stał się tym, czym my jesteśmy, aby uczynić nas tym czym on sam jest" (AH. V przedmowa). Chrystus przyszedł aby człowieka przebóstwić, aby człowiek poprzez wcielenie stał się bogiem poprzez łaskę: „Syn Boży stał się człowiekiem, abyśmy zostali przez niego przyjęci za synów. Dzieje się tak, gdy ów człowiek niesie Syna Bożego, ogarnia go i obejmuje" (AH. III,16,3). W ten sposób grzeszny, zbłąkany i wygnany człowiek zostaje na powrót sprowadzony na swoją drogę, a nawet jeszcze głębiej, włączony do Bożej miłości i nazwany bogiem przez łaskę.

\section{Tradycja i apostolskość Kościoła}

Św. Ireneusz jest pierwszym pisarzem chrześcijańskim, który zwrócił uwagę na znaczenie tradycji i związku Kościoła $\mathrm{z}$ apostołami. Te jego spostrzeżenia wpisują się w ogólny nurt walki z poglądami gnostyków, którzy nie posiadali związku $\mathrm{z}$ nauczaniem apostolskim, a tym samym $\mathrm{z}$ tradycją. Tylko związek $\mathrm{z}$ apostołami gwarantuje prawdziwość nauczania. Jeśli takiego związku nie ma, nauczanie nie może być prawdziwe. Te nauczanie zachowywane jest w Kościele, gnostycy natomiast są poza Kościołem: „Kościół, który dzisiaj jest rozrzucony po krańce ziemi, otrzymał przez apostołów i ich uczniów wiarę w jedynego Boga, Ojca wszechmogącego, stworzyciela nieba i ziemi” (AH. I,10,1). Tylko Kościół, który jest założony przez apostołów może stanowić właściwy i prawdziwy grunt do nauczania wiary. Apostołowie są gwarantami prawdziwości nauczania wiary, która została im przekazana przez Pana. Z kolei apostołowie tę prawdę i tę wiarę przekazali swoim uczniom. Uczniowie apostołów, zaś przekazali tę wiarę następnym pokoleniom, w ten sposób została stworzona pewna sukcesja, która przetrwała do czasów w których żył św. Ireneusz. Ta prawda zachowywana jest w Kościele, nie ma jej natomiast tam gdzie brakuje nauczania apostolskiego: „Tak więc tradycja Apostołów, która została objawiona w całym świecie, jest dostępna w każdym Kościele dla wszystkich, którzy prawdziwie chcą zobaczyć prawdę,, (AH. III,3,1). Poza Kościołem, tj. w nauczaniu gnostyków nie ma tej prawdy, dlatego, że nie są oni związani z Kościołem. Ponadto przypisują oni sobie fałszywie posiadanie wiedzy i prawdy. Ta prawda tkwi w nauczaniu Kościoła i biskupów: „Prawdziwą gnozą jest nauka Apostołów oraz wiara Kościoła w jej całości znana od dawna na całym świecie. Wyróżniającym znakiem Ciała Chrystusa jest następstwo biskupów, którym Apostołowie przekazali Kościół znajdujący się w danym miejscu" (AH. IV,38,8).

Biskup Lyonu uważa, że Kościołem apostolskim jest ten Kościól, który został założony przez któregoś z apostołów. Autorytet jego założenia jest gwarantem prawdziwości nauki Chrystusowej. Z takich Kościołów należy czerpać wiedzę i wiarę, dlatego, że ona jest prawdziwa. Takich Kościołów jest wiele i nie chcąc tracić czasu na wyliczanie ich wszystkich: wymienia trzy spośród nich: Kościół w Rzymie, Smyrnie i w Efezie. Jednak „najbardziej apostolską" naukę widzi w Kościele założonym przez apostołów Piotra i Pawła w Rzymie. Podkreśla, że jest to Kościół wszystkim znany i jego nauka jest rzeczywiście apostolska: „Tymczasem z tym Kościołem z powodu jego szczególnego autorytetu założenia, winien zgadzać się każdy Kościół(...). W nim zawsze została zachowana przez wiernych zewsząd ta tradycja, która wywodzi się od Apostołów" (AH. III,3,2-3). Inne Kościoły apostolskie, również cieszą się takim autorytetem prawdy. Stwierdzenia odnośnie pierwszeństwa Kościoła Rzymskiego często zwłaszcza przez teologów rzymskokatolickich są interpretowane jako odniesienie przyszłego nauczania o roli i prymacie papieża. Jednak chodzi tu raczej św. Ireneuszowi o rolę Kościoła Rzymskiego $\mathrm{w}$ walce $\mathrm{z}$ gnostycyzmem. Przy okazji podkreślenia autorytetu Kościoła Rzymskiego, biskup Lyonu podaje katalog bi- 
skupów tegoż Kościoła. Jest pierwszym pisarzem chrześcijańskim, który wyraźnie przypisuje założenie Kościoła w Rzymie dwóm apostołom Piotrowi i Pawłowi: „Błogosławieni apostołowie, zakładając i organizując Kościół, powierzyli posługę biskupstwa Linusowi” (AH. III,3,3). Następcą Linusa był Anaklet, następnie Klemens, potem Ewarest, Aleksander, Syksted, Telesfor, Hygin, Pius, Anicet, Sotyrus, Eleuteriusz w czasie pełnienia posługi Ireneusza w Lyonie, katerę Rzymską zajmował Wiktor (AH. III,3,3). Taki spis pasterzy Kościoła Rzymskiego ma za zadanie ukazać związek obecnego biskupa $\mathrm{z}$ apostołami, co z kolei gwarantuje prawdziwość nauki tego Kościoła i jego apostolskość. Apostołów Piotra i Pawła określa założycielami tego Kościoła, ale żadnego z nich nie umieszcza pośród pasterzy (biskupów) tegoż Kościoła.

Odnosząc się do szeregu pism, które w środowiskach gnostyckich były określane ewangeliami, św. Ireneusz podkreśla, że prawdziwe są tylko cztery Ewangelie: „Niemożliwym jest aby było więcej lub mniej Ewangelii, niż w rzeczywistości ich jest. (...) gdy objawił się ludziom dał nam czterokształtną Ewangelię podtrzymaną przez tchnienie jednego Ducha”. (AH. III,11,8). Istnienie czterech Ewangelii, które są przeniknięte jednym duchem, porównuje do istnienia czterech stron świata i czterech wiatrów tchnących prawdą. Po raz pierwszy w literaturze chrześcijańskiej pojawia się określenie Ewangelii, Dziejów Apostolskich i Listów Apostolskich jako „Pismo”. Tj. określenie Starego Testa-

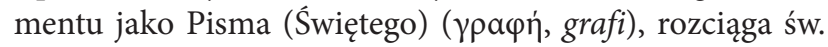
Ireneusz także na Nowy Testament. Pisma te dzieli jakby na dwie grupy: 1) Ewangelie i 2) Pisma apostolskie. W ten sposób Pismo Starego Testamentu i Nowego stanową pewien ciąg w którym Bóg stopniowo lecz konsekwentnie objawia swoją wolę i siebie dla całego rodzaju ludzkiego ${ }^{21}$.

21 Podkreślenie wartości Objawienia Bożego zarówno w Nowym Testamencie jak i Starym było ważnym $z$ tego względu, że gnostycy jeśli nie odrzucali całkowicie Starego Testamentu, to negowali jego wartość.
Odnosząc się do nauczania o Eucharystii, św. Ireneusz nazywa ten sakrament posługując się słowami apostoła Pawła „uczestnictwem w Ciele i Krwi Pana”. Ma ona sens jedynie wówczas kiedy jest wiara w zmartwychwstanie. Gnostycy, którzy odrzucali zmartwychwstanie i uczestnictwo w nim ludzkiego ciała nie mogli we właściwy sposób zrozumieć Eucharystii: „Jeśli ciało się nie zbawia, to i Pan nas nie odkupił swoją krwią, ani kielich Eucharystii nie jest udziałem w Jego krwi ani chleb, który łamiemy nie jest udziałem w Jego ciele" (AH. V,2,2). Eucharystia nie jest symbolem Ciała i Krwi Pana, lecz jest prawdziwym Ciałem i Krwią Zbawiciela. Będąc pokarmem nieśmiertelności Eucharystia czyni nas samych i nasze ciała również nieśmiertelnymi. Biskup Lyonu podkreśla, że dla pełnego zbawienia człowieka, tj. do zmartwychwstania w dniu ostatecznym, przyjmowanie św. Darów jest koniecznym. To właśnie św. Dary pozwalają aby ciało ludzkie, które stało się śmiertelnym w dniu ostatecznym ożyło: „(...) w ten sposób nasze ciała, które są karmione przez nią (Eucharystię) i złożone do ziemi, gdzie przechodzą proces rozkładu, powstaną w dniu, który został wyznaczony" (AH. V, 2,3). „W jaki sposób mogą oni (gnostycy) powiedzieć, że ciało ulega zniszczeniu i nie uczestniczy w życiu, przecież jest ono karmione Ciałem i Krwią Pana" (AH. IV,18,4). Eucharystia jest ofiarą, która składana jest Panu, dlatego, że tak on polecił.

Biskup Lyonu głosząc naukę Kościoła i przeciwstawiając ją poglądom gnostyków wyraził szereg poglądów, które stały się częścią nauczania Kościoła po wsze czasy. Na przeciągu wielu wieków Kościół odnosił się i dalej odnosi się z wielką uwagą i czcią do tego co św. Ireneusz wyraził na początku epoki chrześcijańskiej tj. na przełomie II/ III w. Wiele pokoleń pisarzy i Ojców Kościoła w znaczący sposób korzystało z jego pism, rozwijając i pogłębiając jego poglądy.

\section{Bibliografia}

Ireneusz z Lyonu, Wykład Nauki Apostolskiej, wstęp, przekład i opracowanie W. Myszor, Kraków 1997.

Ireneusz z Lyonu, Adversus haereses (Contra haereses) P.G. 7, 4371224 (Tłumaczenie fragmentów w j. polskim: A. Bober, Antologia patrystyczna, Kraków 1965; M. Michalski, Antologia literatury patrystycznej, Warszawa 1975; Ireneusz z Lyonu, Chwała Boga żyjący człowiek, wybór tekstów i opracowanie J. Comby, D Singels, tłum. W. Myszor, Kraków 1999; Ireneusz z Lyonu, Bóg $w$ Ciele i Krwi, wybór tekstów i wprowadzenie Hans Urs von Balthasar, tłum. W. Myszor, Kraków 2001).

Euzebiusz z Cezarei, Historia Kościelna. O męczennikach palestyń- skich, tłum. i oprac. A. Lisiecki, POK 3, Poznań 1924 (przedruk, WAM, Kraków 1993).

Dekert T., Teoria rekapitulacji Ireneusza $z$ Lyonu $w$ świetle starożytnych koncepcji na temat Adama, Kraków 2007.

Drączkowski F., Patrologia, Peplin-Lublin 1999, s. 93-94

Myszor W., Gnostycyzm i teologia Ireneusza z Lyonu, Zagadnienie wybrane, Studia Antiquitatis Christianae, Series Nova 11, red. L. Lach-Mbartlik, Katowice 2010.

Мейендорф И., Введение в святоотеческое богословие, New York 1985.

Quasten J., Initiation aux Pères de l'Église, t. 1, Paris 1955.

Tatarkiewicz W., Historia Filozofii, t. I, Warszawa 1988. 
ISSN 1508-7719

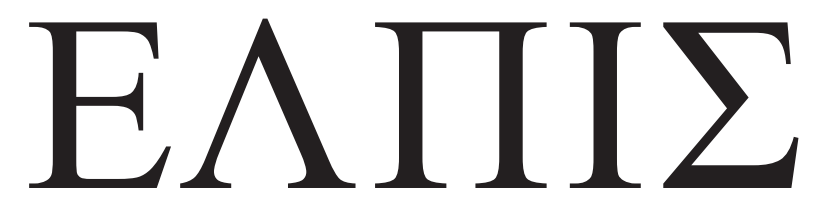

CZASOPISMO TEOLOGICZNE KATEDRY TEOLOGII PRAWOSŁAWNEJ UNIWERSYTETU W BIAŁYMSTOKU

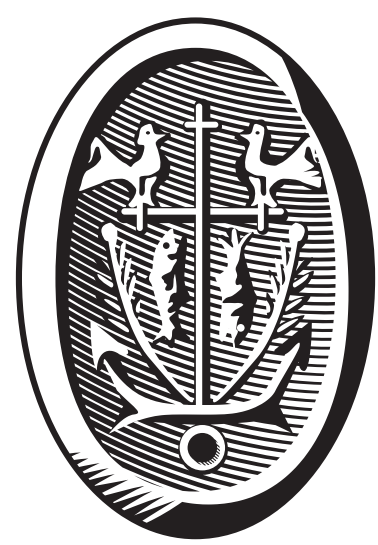

ADRES REDAKCJI

15-097 Białystok, ul. M. Skłodowskiej-Curie 14 tel. 85 745-77-80, e-mail: redakcja@elpis.edu.pl www.elpis.uwb.edu.pl 